\title{
Verbal magic and healing charms in Glasgow University Library Ferguson MS 147
}

\author{
Isabel de la Cruz-Cabanillas \\ University of Alcalá
}

\begin{abstract}
Manuscript Ferguson MS 147, a fifteenth-century volume written in Middle English and housed in Glasgow University Library, contains a copy of the Antidotarium Nicholai, a sarum calendar and a medical compilation which includes medical recipes, prognostic texts, and healing charms. Our interest is placed on the charms in the medical recipe collection found in folios $63 \mathrm{r}-159 \mathrm{v}$. Following earlier studies on the charm genre, we will characterise the medical charms found in Ferguson MS 147 from a linguistic standpoint. This touches upon the use of language and other technical features, such as the presence of code-switching, the use of specialised symbols and characters, and the terminology used by the scribe to refer to the genre, among others. Concerning textual tradition, we also aim to examine whether the healing charms present variation, even if small, with earlier described charms. From a methodological point of view, the comparison includes contrasting our material with other edited compilations of charms.
\end{abstract}

Keywords: charms; Ferguson MS 147; Middle English; medical manuscripts

\section{Introduction}

The present study explores a number of healing charms inserted in a collection of medical recipes in Ferguson MS 147 housed in Glasgow University Library. The manuscript forms part of the collection of John Ferguson, former student and Chemistry Professor at Glasgow University from 1874 to 1915. Ferguson's personal library was extensive, containing approximately 18,000 volumes. After his death, an important part of his collection was purchased by Glasgow University in 1921 (Weston 2004).

Isabel de la Cruz-Cabanillas, Selim26 (2021): 109-128.

ISSN 1132-631X / ISSN-L 2792-3878 / https://doi.org/10.17811/selim.26.2021.109-128 
Glasgow University Library Ferguson MS 147 dates to the beginning of the fifteenth century and comprises 159 folios on paper and parchment, mainly devoted to medical recipes in Middle English. The focus here is on the medical recipe collection found in folios $63 \mathrm{r}-159 \mathrm{v}$. The compilation contains mostly medical recipes for different diseases, but prognostic texts and charms are also included in this miscellany. Apart from the recipe compilation, the manuscript contains the following items: a translation of the alphabetically arranged Antidotarium Nicholai or Antidotary of Nicholas (folios 1r-55v) and a sarum calendar in Latin (folios 57r-62v). The text presents some annotations after the Antidotarium Nicholai as well as on both sides of folio 91, where some recipes were added in a sixteenth century hand. Likewise, at the end of the manuscript a sixteenth-century hand added some recipes for conserves and two charms on the flyleaves (one on folio 158v and another one on folio 159v). Manuscript Ferguson MS 147 is of interest, first, for containing a considerable number of diverse Latin and Middle English charms compared to other recipe collections of the same period and, second, for being an unexplored collection thus far.

The article is structured as follows: after the brief introduction to the manuscript under consideration, the methodology adopted is explained. Both a classification according to the purpose or the disease and another according to contents, method, and discursive strategies following Hunt's taxonomy of charms are provided. Afterwards, the analysis of the charms found in the Middle English recipe compilation and their linguistic features, as well as the results of the comparison with the same charms in other Middle English manuscripts, are discussed. Then, the findings drawn from the investigation are summarised in the conclusions. Finally, the references for the presentation are supplied in the corresponding section.

\section{Healing charms in Ferguson MS 147}

The Oxford English Dictionary defines charm as "the chanting or recitation of a verse supposed to possess magic power or occult influence; incantation, enchantment; hence, any action, process, verse, sentence, word, or material thing, credited with such properties; a magic spell; a talisman, etc.”. Despite the definition, charms in Middle English manuscripts are not always in verse and appear usually along recipes and prognostic texts.

Smallwood emphasises the fact that "the innumerable collections of brief remedies produced in the same period in England show without any doubt that 
highly literate men (if they were all men) regarded charms as being, potentially, as useful as the physical or pseudopharmaceutical prescriptions and treatments among which they were collected" (2009: 87-88). The tradition of regarding charms as useful medical remedies goes back to Old English, when numerous charms have been attested. While charms could be used for other purposes, such as to keep thieves away, the charms in Ferguson MS 147 are exclusively for healing purposes. According to Olsan, not every medical condition was to be cured by means of charms and prayers: "Most of the problems for which charms or prayers are prescribed in these texts are chronically remitting or episodic conditions whose recurrence a sufferer would want to take steps to prevent. Such are toothache, migraine, fevers, seeing 'spots', spasms, cramps and temporary paralysis, nosebleeds (and other intermittent bleeding), insomnia, epileptic seizure, and gout" (Olsan 2003: 358). On the same page, she adds that "acute conditions can also be found. These include bleeding, difficult childbirth, certain fevers, a seizure in progress, poisonous bites, and puncture wounds" (ibid.). As happens in other cases, medieval charms in Ferguson MS 147 are "devotedly Christian" (Smallwood 2009: 88). Subsequently, plenty of religious references are to be found.

In Ferguson MS 147, charms appear intermingled with recipes with no mark acknowledging their specific nature. All medieval charms, ${ }^{1}$ even one recommended for insomnia that was crossed out on folio 81r, are taken into consideration for the present analysis. Thus, a corpus of thirteen charms has been collected, four of which are in Latin and nine in Middle English, including some dubious cases related to the use of the herb vervain. This combination of Latin versions alongside Middle English ones is usually documented throughout the period (Olsan 2018: 11). The diseases covered can be seen in Table 1.

\footnotetext{
${ }^{1}$ The charm added in the sixteenth century for toothache has not been included in the analysis (f. 159v), which concentrates on medieval charms. No medieval versions of this specific incantation have been found thus far.
} 
Table 1. Medical condition and corresponding medieval charm in Ferguson MS 147

\begin{tabular}{|c|c|c|}
\hline $\begin{array}{l}\text { Medical } \\
\text { Condition }\end{array}$ & Middle English & Latin \\
\hline Child delivery & & $\begin{array}{l}\text { - Beata anna peperit sanctam } \\
\text { Mariam verginem (with a } \\
\text { title in ME, ff. } 66 \mathrm{v}-67 \mathrm{r} \text { ) }\end{array}$ \\
\hline $\begin{array}{l}\text { To stop } \\
\text { bleeding }\end{array}$ & $\begin{array}{l}\text { - Whan oure lorde Ihesu cryste ... } \\
\text { come longeus (f. 66v) } \\
\text { - Cryste was bornn at bedelym \& } \\
\text { yfollyd in flom Iurdan (f. 69v) } \\
\text { - Wryte aboue pe place pat bledyp } \\
\text { in a man beronix and in womman } \\
\text { beronixa (f. } 76 \mathrm{r} \text { ) }\end{array}$ & $\begin{array}{l}\text { - Longius miles (with a title } \\
\text { in ME ff. } 75 \mathrm{v}-76 \mathrm{r} \text { ) } \\
\text { - Te per eum sanguis exiunt } \\
\text { coperfidus occidit agnus (with } \\
\text { a title in ME, f. } 76 \mathrm{r} \text { ) }\end{array}$ \\
\hline For a cough & - Kyryeleyson xristeleyson (f. 73r) & \\
\hline $\begin{array}{l}\text { To make a } \\
\text { man slepe }\end{array}$ & $\begin{array}{l}\text { - Take \& wryt pese wordys } \\
\text { (f. } 81 \text { r) }\end{array}$ & \\
\hline Epilepsy & $\begin{array}{l}\text { - Pro morbo caducoo (with a title } \\
\text { in Latin, ff. } 124 \mathrm{v}-125 \mathrm{r} \text { ) }\end{array}$ & \\
\hline Tertian fever & - ffor the feuer tercyan (f. 140r) & \\
\hline Toothache & & $\begin{array}{l}\text { - Christus vincit }+ \text { Christus } \\
\text { regnat }+ \text { Christus imperat } \\
\text { (f. } 158 \mathrm{v} \text { ) }\end{array}$ \\
\hline $\begin{array}{l}\text { Foretell } \\
\text { whether a man } \\
\text { will live or die } \\
\text { and others }\end{array}$ & $\begin{array}{l}\text { - To know were a syke man schal } \\
\text { lyue or dye (f. } 69 \text { r) } \\
\text { - Also who so berep verueyne } \\
\text { vpon (f. } 100 \text { r) }\end{array}$ & \\
\hline
\end{tabular}

Hunt (1990: 78-82), following Payne (1904), classifies charms into six groups, taking into consideration their contents, method, and discursive strategies. This is the taxonomy adopted for the present study, which includes the following types: 
i) Prayers invocations and other verbal formulae addressed to the herbs.

ii) Prayers and mystical words repeated over the patient, or written or applied to some part of his body as an amulet.

iii) Direct conjurations or exorcisms addressed to diseases.

iv) Narrative charms.

v) Material Magic.

vi) Transference of disease by a verbal formula, or a ceremony, to some animal or material object.

Thus, the Ferguson MS 147 charms will be analysed according to the previously mentioned classification.

i) Prayers invocations and other verbal formulae addressed to the herbs. This category contains directions on how to gather the medicinal herbs. Olsan (2003: 359) illustrates this type with a charm from Harley 2558 that includes the propitious moment to collect the herbs. No charm of this kind has been found in Ferguson MS 147.

(1) Whan th[o]u gederest ane herbe to mannes helpe, go thryes aboute hym and sey this: ' $Y$ take the herbe yn the name of the fader and the sone and the holy gost. And Y pray to my Lord God that thys herbe be god and virtues to the medicine that $Y$ have ordyned hym to.' And sey thre pater nosters \& iii ave marias. And whan thou hast gedred thyn herbys al the yer or a sesonne, gyfe this blessynge upon hem and sey thus.

ii) Prayers and mystical words repeated over the patient, or written or applied to some part of his body as an amulet. The indications refer to the formulae and words that should be mentioned to overcome the disease. The words may be written on parchments to be placed around the patient's neck or on the affected body part. The examples from Ferguson MS 147 are the following:

(2) Anothur seye kyryeleyson xristeleyson $\&$ gape vp warde $\&$ ley pi hondys to pi prote \& hold a whyle pi brethe as longe as pou mayste. (f. 73r)

(3) Alle so wryte aboue pe place pat bledyp in a man beronix and in womman beronixa yt schal stanche pe blode. (f. 76r) 
The latter refers to Saint Veronica's figure, who wiped Jesus Christ's sweat with her veil when he was carrying the cross. Even if this passage is not found in the Bible, it is part of the Christian tradition. In fact, Mitchell (2011: 146-147) acknowledges the Veronica's reference in manuscript Ashmole 1435 with almost the same formulation in Latin: "fac crucem in fronte et scribe berenix et si sit femina beren<ices" ('make the sign of the cross on the forehead and write berenix and if it is a woman berenice').

Other samples give instructions on "how to make a man slepe" (4) and "how to cure a tertian fever" (5), as well as example (6) for morbo caduco ('epilepsy'):

(4) Take \& wryt pese wordys \& ley hem vndur his hed pat he whete nozt per Ismaell conniure te per angellum mychaell vt sopetur homo yste. (f. 81r) ${ }^{2}$

(5) ffor the feuer tercyan ffor pe ffeuer tercyan Take the branches of wey brede aftur the sonne ys down \& sey iij pater noster $\&$ iij aue $\&$ poune hem wel togedur $\&$ temper hem with holy watur $\&$ make hym to drynke per of whan yt takep hym. (f. 140r)

(6) Pro morbo caducoo Take blode of pe lytul fynggur of the ryght honde pat is syke $\&$ wryte pese iij namus in parchement with pe blod of the man pese byn the wordus Iespar + Melchisor + Melchior + balchizar + And lete close yt $\&$ hange yt abowte his necke pat is syke $\&$ ar pou close yt put per yn gold \& myrre \& franckyn sense of eche a lytille $\&$ bynde hym whan he rysep of his bed ilke a day with pese iij namus \& sey for her sowlus iij pater noster \& iij aues \& ilke a daye of a monthe drynke pe rote of the pyenyze with stale ale $\&$ he schal be hole sycurly \& zef yt be a childe ynnocent drawe blode of the same fyngger pat is before seyde \& wryte pee kyngus namus on a masere with the blode $\&$ waysche yt with ale oper mylke \& late the childe drynke yt $\&$ sanabitur. (ff. $124 \mathrm{v}-125 \mathrm{r})^{3}$

\footnotetext{
${ }^{2}$ This charm has been crossed out in Ferguson MS 147. As a result, some letters cannot be properly identified. A version occurs in Pahta (2004: 89) and reads "exmael exmael aiuro te angelum michaelem ut soporet homo ille". In turn, Olsan (2004: 66) uses the formula "Ismael + Ismael". Although only the title is given, presumably it must be the same formulation, since it is for the same purpose. Finally, Alonso-Almeida (2014: 107) records a variant where Ismael is not mentioned, but the final part is similar to the text in Pahta above, "adiuro te per angelum mychaelium vt soporet homo iste".

${ }^{3}$ Forbes (1971: 305) refers to this charm gathered from Peter Levens' in A Right Profitable Booke for All Disseases, and Mitchell (2011: 190) discusses it in the version included in San Marino, Huntington Library 1336.
} 
Similarly, another instance of a charm containing well-known formulae is found on folio 158v. This invocation to Christ was added on a sixteenth-century hand, but the wording of the charm is well rooted in the medieval tradition (Olsan 2018: 13). The secretarial handwriting is hardly legible and the paper was cut out at some point, which makes the reading even more complex, but the middle part reads:

(7) + Christus vincit + Christus regnat + Christus imperat + Christus qual locum et sum familium ab onum malo protegat et defendat amen et dic evady Sancti Iohannes et dic vij pater amen v aves et Thre credo. (f. 158v) ${ }^{4}$

The purpose of this charm is unclear, but other similar charms, such as those in Hindley's and Olsan's compilations, are not. On the one hand, Hindley records this formula in charms for toothache; namely BL, Add 33996 f. 138v, British Library Wolley Ch iv 68, and Cambridge, Corpus Christi College MS 308 p. $17 .{ }^{5}$ On the other, Olsan (2018: 13) presents examples where the invocation is used for diverse kinds of fever.

iii) Direct conjurations or exorcisms addressed to diseases. The functions of these charms are to expel the disease or cause of the medical disorder. According to Payne (1904: 127), "charms of this particular kind do no often appear in medieval books". In Ferguson MS 147 the following are found:

(8) Medicyn for to staunche blode ffyrste pou moste yn wote the mannys name \& than go to churche $\&$ sey pis scharme $\&$ loke pou seye yt for no beste bot for man or for womman this charme iij the daruoztryche Weper yt be for man or for womman but pat pou knowe his name \& sey pus $\mathbb{I}$ Whan oure lorde Ihesu cryste was don on pe rode or was don on pe crosse pan come longeus \& stonge hym with his spere yn his syde bloode \& watur come. ouzt at his wownde he wyped hys yzen \& seye a none poroz pat holy vertu that god. dyed thare y coniure the blode pat pou com nozt ouzt of pis crystyn man \& nemny his SS In nomine patris \& filij \& spiritus sancti amen verum est. (f. 66v)

\footnotetext{
${ }^{4}$ I am grateful to Dr Ivalla Ortega for helping decipher this difficult passage. Errors are obviously my responsibility.

${ }^{5}$ My thanks to Dr Katherine Hindley for sharing these samples from her collection with me.
} 
(9) Sey pis cryste was bornn at bedelym \& y follyd in flom Iurdan also pe flom stode \& also stonde pi blode In nomine patris \& filij. (f. 69v)

(10) Te per eum Sanguis exiunt coperfidus occidit agnus et sangris cuius per erum sancti fuit huius ad iutocessa nunc vena vale que repressa ter dicatur. (f. 76r)

Regarding example (10), it is worth mentioning that the scribe may not have been conversant with Latin, as Forbes (1971: 299) records this charm and translates it as "Thou from whom flowed the blood by which the treacherous serpent dies, \& whose sanguis cuius precium seculi fuit huius, adiuro cessa, nunc vena valeque repressa”. In Ferguson MS 147 the word used is not anguis 'serpent' but agnus. The latter appears with an ending -us abbreviated as a superscript resembling number 9 and the only hesitation would be how to interpret the minims after $<\mathrm{g}>$. They could be rendered as $<\mathrm{u}>$ producing a form like aguus, which makes no sense in Latin, or as agnus. Likewise, other words do not seem to have been interpreted correctly by the scribe or he may be quoting from a corrupted source, which results in non-existent Latin forms.

iv) Narrative charms. Usually these are the commonest type of charms (Hunt 1990: 81). This category resorts to stories, mainly from the Christian tradition. The invocation of these holy people is supposed to make the sick person heal. It is very often used for the staunching of blood. Thus, we usually find different versions of how the lance of Longinus pierced Christ's side and more specific details about how the blood and water flowed from the wound are described. In Ferguson MS 147 one reads:

(11) A scharme for to stanche blode longius miles lancea latus domini perforauit et ocius exiuit Sanguis et aqua sanguis redempcionis aqua baptismatis In nomine patris restet sanguis In nomine filij restet sangris In nomine sancti restet sangris $\&$ ampliuus ab hac vena ut ab hac plaga non exeat sangris In nomine patris et filij et spiritus sancti amen. (ff. $75 \mathrm{v}-$ 76r)

Also in Latin, a charm for a difficult delivery with an English title Another is found in Ferguson MS 147. Here a series of Biblical figures drawn from the New Testament are mentioned. Thus, beginning with Beata Anna, who gave birth to virgin Mary, Jesus Christ's mother, along with the apostles and all saint 
men and all saint confessors as well as all saint virgins are invoked to help deliver the baby:

(12) Beata anna peperit sanctam mariam verginem Matrem dium nostri Ihesu Xristi et sancta maria peperit filium dei per istam Nativitiatem ego credo istud quod omnes ypinam amorte et ali omni periculo possit liberari Sancta maria dei genitrix \& omnes sancti apostoli et omnes sancti vertures et omnes sancti confesores $\&$ omnes sancti vergines intercedant pro famula tua SS Amen. (ff. 66v-67r)

This is one of the most widely spread charms in the Middle Ages. Braekman elaborates on the procedure explaining that a periapt should be laid on the woman's womb. This is "a long strip of parchment bearing Latin text which says that Mary brought forth the child Jesus who save mankind free through the shedding of His blood" (1986: 122). Related charms are documented in Henslow (1899: 32-33) and Ogden (1938: 57).

v) Material Magic. In this category, plants, stones or parts of animals are attributed some magical powers. Here we find several examples in Ferguson MS 147 , where vervain is said to have magical powers, so that it can predict whether a patient will live or die, as in (13), or will grant the person who carries it love and grace, as in (14):

(13) To know were a syke man schal lyue or dye Take verueyne \& bere yt in pinne honde $\&$ come to syke man \& sey to hym pus SQ how ys yt with the $\&$ zef he answere $\&$ sey wele he schal lyue $\&$ zef he sey euell of or suche a pinge he schal dye. (f. 69r)

(14) Also who so berep verueyne vpon hym he schal haue loue \& grace of grete maysteris \& pei schul grawnte al his askynge that is good \& skylfulle $\&$ nozt refuse his askynge be no maner wey. (f. 100r)

The examples in (13) and (14) are on the border of the category of charms. For the first, Olsan (2009: 219) provides example (15) whereby the vervain should be held in the right hand: 
(15) For to weten if a sik man nogt wounded schal leue or deye Also. Take fiue croppes of verveyne with pi rigt hand \& ley in pi lefte $\&$ sey ouer hem .v. pater noster in pe worschip of pe .v. Woundes of Crist \& sey pus: I coniure yow fiue croppes in pe vertu of be .v. woundes bat + Crist suffred on pe rode tre forto bye mannis soule out of thraldom pat pe sik man $\mathrm{N}$ [ame] telle me pe sothe poru pe vertu of God and of yow wheter he schal leue or deye of pat siknesse. \& bless hem .v. times \& ley hem in bin rigt hand agen. \& tak pe sik be his rigt hand so pat he wete nogt of pe erbes. \& what pu axest he schal telle soth of his stat. (ff. $43 \mathrm{v}-44 \mathrm{v}$ )

The main difference lies in the fact that after that, other identifiable elements can be read in Olsan's passage, namely references to Christ, the verb sey, and some prayers like the pater noster. Apart from the formula sey to bym, all the other elements are absent in the Ferguson MS 147 example. Subsequently, in Ferguson MS 147 it seems to be a diagnostic text rather than a charm, since there is no magic in the procedure. All in all, Holthausen (1897: 77) presents a similar charm lacking the above-mentioned elements, as can be read in (16):

(16) To wetyii zif a man [s]chal deye. I Also zif pi good frend be seke, take pis erbe in pi rythand and take his rythand in pi rythand, and lete pe erbe be betwene, pat he wot not, and aske qhow he faryth and qhow he hopith of hym-self? And 3 if he say, he schal leue and fare wel, he schal leue; and 3 if he say, he wot well certayn pat he schal deyin, he schal be ded of pat seknesse.

Finally, Mitchell (2011: 189) gathers the charm in San Marino, Huntington Library 1336 whose resemblance to the charm in Ferguson MS 147 is remarkable:

(17) For to knowe wheper a seke man schal lyue or deye. Nyme verueyne and bere yt yn pyn hond and come to pe seek man and sey to hym pus scilicet 'how ys yt wyt pe' and zyf he answer and sey 'wel' he schal lyue and zyf he sey 'euyle' or ony sweche pyng he schal deye.

The examples in Ferguson MS 147, (13)-(14), clearly follow the tradition of attributing vervain magical powers. The presence of the herb would cause the patient to speak his or her fate truthfully, offering the physician an accurate prognosis, but in (14) the mere fact of his carrying of the herb seems to supply the man with love and grace. 
A similar example where it is not clear whether a herb will work as an amulet is an instance where peony is recommended for epilepsy. It looks like a recipe where the herb is to be eaten and drunk with wine, but there are also instructions to hang it around the patient's neck which makes us think it could work as an amulet to cure him from epilepsy:

(18) ffor the fallynge yuel ete yt \& drynke yt with wyne $\&$ also hange pe rote abowt his necke \& yt schal saue hym withyn xv dayes. (f. 95r)

vi) Transference of disease by a verbal formula, or a ceremony, to some animal or material object. No examples of this kind has been registered in Ferguson MS 147, but Alonso-Almeida (2008: 13) includes one from Glasgow University Library, Hunter 185:

(19) For to stonche blod of pe nose or of wat place yt be of a man. Lat hym drynke pe jus of ache $\&$ ley of pe pounynge to ys forhed azenes pe cros of ys nose, or wryt pese leters in two leues of perchemyne. Bynd yt betwene py pyys $\&$, 3 if pou leuestd nazht me, tak \& wryt hem vp on a knyf. perwyp steke a swyn \& pe rennynge of pe man schal be muche pe lasse. Des bep pe letris: $+p+G+C+p+e+u+o+t+a+$ ges $+i j+u+i i i j+$ etc. + Arisme cladauis ++++ Arisme cladauis ++++ Arisme cladauis +++

\section{Linguistic features}

Charms present recurrent topics which will be organised in a particular sequence and will be realised by specific language. As for the contents, Smallwood (2009: 88) refers to the fact that "the typical healing charm consists of a brief sacred narrative (usually taken from the life of Christ, much less commonly from a saint's legend) or some statement of sacred truth, followed by words saying or implying 'as surely as this is true [...]' or 'in the same way [...]' and an appeal for help or cure. This makes them close to set prayers, which by long Christian tradition can also contain charm-like invocation of familiar sacred truth". The charms in Ferguson MS 147 tend to conform to the contents mentioned above.

In turn, Olsan (2004: 61) focuses on the structure of charms: 
a) the heading or tag indicating the purpose of the charm;

b) a short ritual formula, such as In nomine + patris filii et spiritus sancti or Amen;

c) the incantation proper or operative words which may take a variety of linguistic patterns;

d) directions for performance of the incantation (such as to say it a certain number of times or write it);

e) application to the patient, including accompanying prayers, ritual actions, or herbal remedies;

f) an affirmation of effectiveness.

In the same vein, Alonso-Almeida (2008) has defined charms as a genre and has subsequently described the main linguistic features found in this text type. $\mathrm{He}$ argues that the generic structure will follow the sequence below, where the parentheses represent optional stages and the circumflex shows fixed order, whereas an asterisk implies variable position within the text:

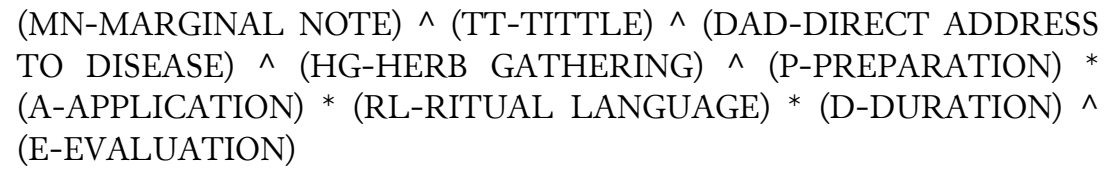

In Ferguson MS 147 there are no marginal notes to signal the medieval charms, but most charms follow this structure, since they present several of these stages. They are usually introduced by a title that may be in Latin or Middle English. Thus, some Latin charms have their title in Middle English, namely the two charms for the staunching of blood. Likewise, an English charm may have its title in Latin, as is the case of Pro morbo caduco for epilepsy. The phenomenon of code-switching is very common in medical texts. The influence of Latin on English medical texts has been evaluated by Pahta (2004) and others. The scribe often integrates Latin within the English text in a very subtle way. As this is not a compulsory stage in the structure, the charm may have no title or it can be something like a charme for, a medicine for, or simply another, as happens in the case of Beata Anna Maria peperit and sey kyryeleyson xristeleyson. According to Alonso-Almeida (2008: 22), the pronoun another has a cohesive function and works as "an anaphoric device and the reader must look backwards in the text for reference". Thus, the Beata Maria peperit charm is immediately preceded by a remedy To make a man schal nouzt blede and the kyryeleyson xristeleyson charm 
by a remedy entitled Medycyn for zoxynge. The use of the word charm to introduce the procedure is important in genre terms, because it reveals the scribes' awareness of the type of texts they were copying. In fact, they are four instances of the word in three different charms.

The next optional stage is Direct Address to the Disease, whose function is to exhort the disease to leave the patient's body. It may be present in the form of performative verbs, such as coniure when the charm is in Latin. These verbs appear in the imperative mood, often accompanied by a second person pronoun, as in one of the charms for staunching blood "y coniure the blode pat pou com nozt ouzt of pis crystyn man" (f. 66v). The performer is conjuring Christ's blood on the rood and recites the charm, so that it will have the desired effect. The presence of pronouns in the first and second person, both in subject position, is another aspect of this specific example.

The Herb Gathering stage contains information related to when and how a given herb should be gathered to maintain its powers, but this stage is absent in our corpus of charms. The function of the Preparation stage can be any of the following: (i) to show how to perform a ritualistic action, (ii) to describe how a remedy must be elaborated, or (iii) to give the ingredients needed to produce a remedy (Alonso-Almeida 2008: 24). The verbs used in this stage will also be in the imperative mood; for instance, in the charm against epilepsy: "Take blode of pe lytul fynggur of the ryght honde pat is syke \& wryte" (f. 124v). As in recipes, the instruction often involves the use of the verb to take, but the difference with the recipe text lies in the fact that charm verbs, such as to say or to write, are essential components of the charm genre, since the words will work the miracle along with the other ingredients usually found in recipes; here namely blood.

Words are the main healers in charms along with the process that must be performed in a particular way. Thus, in one of the charms to staunch blood, it is specified that some words must be written on the patient's body: "wryte aboue pe place pat bledyp in a man beronix and in womman beronixa" (f. 76r). The writing of the letters will work as the remedy, since placing the letters above the bleeding part will have a performative effect: to stop bleeding.

Afterwards, the Application stage shows how to perform the ritual action and how the product should be administered. The linguistic constituents will be (i) use of verbs in imperative, (ii) presence of verbs with coercive meaning, and (iii) use of personal pronouns both in subject and object position (AlonsoAlmeida 2008: 27). Direct commands are seen in "seye pis ouer pe womman that traueylep" (f. 66v), while the use of pronouns has already been mentioned above. 
Then comes the Ritual Language stage which serves to give the words and prayers required for the implementation of the charm. The presence of classical languages is common at this stage, as described by Pahta (2004: 88):

Some Latin prefabricated utterances act as performatives, and have a 'doing-itby-saying-it' effect. As the performatives in the texts are connected with medicinal powers, they can also be seen as part of the special language of contemporary medical practice. Like in prayers, the function of the code is to enhance the power and efficacy of the words.

Pahta adds that "a related group of switches contains instances of Latin, sometimes combined with transliterated Greek or Hebrew, in religious charms for medical purposes". The study of charms in languages other than English are equally important for the study of the English language, since, regardless of the language of the incantation, the instructions are given in Middle English (Keiser 1998: 3670). The instructions are often conveyed through religious vocabulary, so we find formulae such as kyryeleison xristeleison (f. 73r) or in nomine patris et filij et spiritus sancti (f. 66v). Other words are also common: aue (maria), pater noster, amen, sancta, dei, in Latin, but also churche, rode, lord Ieshu, flom Iurdan, bedelym, wownde, in English.

The Duration stage may be present, such as in the charm against epilepsy, where the charm is prescribed each day for a month: "whan he rysep of his bed ilke a daye with pese iij namus \& sey for her sowlus iij pater noster \& iij aues $\&$ ylke a daye of a monthe" (f. 125r). Finally, the Evaluation stage can be found as well. Its purpose is to assure the reader the efficacy of the process. It can be conveyed through Latin, as it happens in recipes, with the formula sanabitur or verum est. As in recipes, the charm may finish with the English sentence be schall be bole (f. 125r) or a reformulation of the title as in $y t$ schal stanche pe blode (f. $76 r$ ), or simply shows no proof of its efficacy.

To conclude this section, we could adopt Jucker \& Taavitsainen's words for whom "genres show different realisations in different periods, but more prototypical features may remain constant in a long diachronic perspective" (2013: 147). The fact that the main basic constituents remain implies that there are few variations in the formulation of charms either in Latin or in English. Thus, similar elements are found in the Latin-based tradition of charms and in those either coined or translated into English. 


\section{Comparison with other Middle English charm compilations}

As Roper (2009: xiv) has observed, most charms "were to be found all over Europe". As a result, it is expected that the charms present in Ferguson MS 147 can be located in other Middle English manuscripts and possibly in other textual traditions. Focusing on Britain, Smallwood (2009: 87) specifies that "in England in particular, in the fourteenth, fifteenth and early sixteenth centuries, charms were not the arcane material of personal performance, but rather something to be shared, often in writing". Thus, the textual tradition of this genre must have been recorded in writing and parallel texts are likely to be found in other medical treatises or recipe compilations. In fact, some of the charms in Ferguson MS 147 are widely spread and its dissemination process presents the reader with linguistic variation, although the essence of the charms remains untouched.

Smallwood (2004: 15) estimates that between 1370 and 1540 there are three hundred copies of charms in English, half of which correspond to versions of Flum Jordan and Longinus motifs. Thus, these two charms are the most likely to be found in other compilations. For comparison, the following charm collections have been searched due to the extensive number of texts included: Holthausen (1897), Payne (1904), Forbes (1971), Hunt (1990), Olsan (2003, 2004, 2009), and Braekman (1986), also included in the charm section of the Middle English Medical Texts (2005). The results can be seen in Table 2, which shows whether the charm is present for the same purpose. It is worth noting that, while Olsan (2003) has gathered numerous examples from different sources, the text of the charm is not offered, and, as a result, the specific words used cannot be checked; the index provided, where charms are classified according to their purpose, has been used nonetheless. On the contrary, Holthausen (1897) and Forbes (1971) include the text of the charms.

As can be deduced from the table, the most widely spread charms are Beata anna maria peperit, Longinus miles, Flum Jordan, Whan oure lord, and Iasper + Melchior + Baltasar, which are documented from four to seven times in the eight sources, while the Beronix charm appears in three sources. Two compilations record the charm to make a man sleep and the vervain used to predict whether a patient will live or die, whereas not a single instance has been found thus far of the following two charms: the vervain to get love and grace, and the kyrylieson xristielyson formula for coughing. Nevertheless, Katherine Hindley kindly let me know that the formula kyrylieson xristielyson is found for coughing in her compilation at least on three occasions, for which see (20), (21), and (22). 
Table 2. Motifs in Ferguson MS 147 compared to other charm compilations

\begin{tabular}{|c|c|c|c|c|c|c|c|c|}
\hline \multirow{2}{*}{$\begin{array}{l}\text { Ferguson } \\
\text { MS } 147\end{array}$} & Holthausen & Payne & Forbes & Braekman & Hunt & \multicolumn{3}{|c|}{ Olsan } \\
\hline & 1897 & 1904 & 1971 & 1986 & 1990 & 2003 & 2004 & 2009 \\
\hline $\begin{array}{l}\text { Beata Anna } \\
\text { peperit }\end{array}$ & & + & + & + & + & & + & + \\
\hline $\begin{array}{l}\text { Longinus } \\
\text { miles }\end{array}$ & & + & + & $+^{6}$ & + & + & + & + \\
\hline $\begin{array}{l}\text { Per eum } \\
\text { sanguis }\end{array}$ & & & + & & & & & \\
\hline $\begin{array}{l}\text { Whan oure } \\
\text { lord }\end{array}$ & + & & & & + & + & + & + \\
\hline Flum Iordan & + & & + & & + & & + & + \\
\hline Beronix & & + & & & & + & + & \\
\hline \multicolumn{9}{|l|}{$\begin{array}{l}\text { Kyryeleyson } \\
\text { xristielyson }\end{array}$} \\
\hline Ismael & & & + & & & & + & + \\
\hline $\begin{array}{l}\text { Iasper }+ \\
\text { Melchior }+ \\
\text { Baltasar }\end{array}$ & & & + & & & + & + & + \\
\hline \multicolumn{9}{|l|}{ Feuer tercyan } \\
\hline $\begin{array}{l}\text { Cristus } \\
\text { regnat }\end{array}$ & & & + & + & $+^{8}$ & & & \\
\hline $\begin{array}{l}\text { Vervain to } \\
\text { live or die }\end{array}$ & + & & & & & & & + \\
\hline $\begin{array}{l}\text { Vervain for } \\
\text { other purposes }\end{array}$ & & & & & & & & \\
\hline
\end{tabular}

(20) an oper Sey . kyriel . xre.1 . hyrl . 7 hold py hed upwarde 7 pi honde by fore pey prote 7 holde | so pi bre?th inne . also longe ast pu mayst. (Cambridge, Magdalene College, Pepys MS 878, p. 68)

${ }^{6}$ Longeus appears in the charm of tre boni fratres or the three good brothers.

${ }^{7}$ Whan oure lord is also found in Manuscript Wellcome 406.

${ }^{8}$ The charm in Hunt is for staunching blood (1990: 95) and not for toothache. 
(21) ffor hym pat yesketh [...] Anoper / seye kyrie / | leyson / xreleyson / kyrieleyson / 7 hold py mowp | upward and pyne handys before py prote 7 | hold so by breep as longe as pu myght and it / wole staunche // (BL Sloane MS 1764, f. 23v)

(22) [ffor hym pat $\mid$ ziskes] [margin: An oper] Say kyrieleison . xreleison . kyrieleison 7 hald thyn heued vpwarde (Lincoln Cathedral Library MS 91, f. 288r)

Finally, regarding the charm for tertian fever in (5) above, it is not found in any of the consulted sources. However, a close one is found in the latter compilation in Leecbbook for the quartan fever (ff. 36v-37r): "For be feuer quartayn. Nim pe plauntes of waybrode $[\{b\{]$ e for pat pe sonne go doune and say pre pater noster and tempre hit wit holy water and zif hit him to drinke wanne he quakit." Similarly, the Christus vincit charm is found both in Forbes (1971) and Braekman (1986) for childbirth as part of the Beata Anna peperit formula, and mentioned in Olsan (2004: 66) for the same purpose.

Our findings agree with those recorded in other studies. Thus, Keiser (1998: 3670-3671) claims that the Flum Iordan charm "may be the most widespread of all Middle English charms. Verse and prose versions of it reputedly occur in well over 100 manuscripts from all regions. Apparently derived from Latin antecedents extending back to the ninth and tenth centuries". He also attests the popularity of other charms present in Ferguson MS 147, such as the Longinus charm, Lord that hangs upon the rood, the Magi charm, and the Maria peperit Christum charm.

\section{Conclusions}

The present study on the charms in Glasgow University Library Ferguson MS 147 is relevant to academia, since the charms in the recipe collection have never been explored thus far. Apart from proper medical recipes and prognostic texts, thirteen medieval medical charms have been identified. The corpus includes both Latin and English charms, out of which nine are written in English, although code-switching is especially remarkable in the titles. Likewise, the four Latin charms are often introduced by a title in English.

Evidently, the compiler, as well as practitioners and readers, viewed the charms as another form of therapy equivalent to the herbal remedies. The medical problems that the charms relieved or prevented in this specific 
manuscript are mainly limited to these: bleeding, insomnia, epilepsy, the labour of childbirth, fever, and coughing.

In terms of the analysis of the charms recorded in Ferguson MS 147, Hunt's taxonomy (1990) was adopted to classify the corpus. The results show that no instances are found of the first category, namely: (i) Prayers invocations and other verbal formulae addressed to the herbs. On the contrary, out of the thirteen recorded charms, the category that ranks higher is number (ii) Prayers and words repeated over the patient, where six instances are attested. The corpus also records three charms in category (iii) Direct conjuration or exorcism addressed to the disease. Two more charms belong to category (iv) Narrative Charms, and two more are included within number (v) Material Magic. A dubious case here is another instance prescribing the intake of peony, which suggests the hanging of the plant around patient's neck that could act as an amulet. Regarding (vi) Transference of disease by a verbal formula, or a ceremony, to some animal or material object, no instances are documented in the manuscript.

Concerning the linguistic features of the charms, we can conclude that most of them follow the usual pattern established by previous researchers, whereby a title is followed by a direct address to the disease. After that, the reader can usually find the preparation and application stages which precede the ritual language and the duration the treatment is meant for. Finally, certain charms may present an evaluation phrase showing their efficacy.

As far as the textual transmission is concerned, it can be concluded that some charms, like Beata anna maria peperit, Longinus miles, Flum Jordan, Whan oure lord, and Iasper + Melchior + Baltasar, were firmly rooted in the sources and widely spread. Others are not so common but definitely feature that devoutly Christian flavour, which allowed them to be transmitted from generation to generation.

The main conclusion drawn from the analysis is that the samples in Ferguson MS 147 are clear instances of the charm genre. Charms may have been the last resort, but they clearly pursued a distinguishable aim in the medieval culture in which they were inserted: the healing of the sick person through the power of words as a result of ritualistic processes and ritual language. The title of the article Verbal magic and healing charms can never be said to be more appropriate. When medical remedies did not work, medieval people resorted to words that will heal the patient magically. 


\section{References}

Alonso-Almeida, F. 2008: The Middle English Medical Charm: Register, Genre and Text Type Variables. Neuphilologische Mitteilungen 109.1: 9-38.

Alonso-Almeida, F. 2009: Stance Marking and Register in Middle English Charms. Studia Anglica Posnaniensia 45: 13-29.

Alonso-Almeida, F. 2014: A Middle English Medical Remedy Book from Glasgow University Library MS Hunter 185 (Middle English Texts, 50). Heidelberg, Carl Winter.

Braekman, W. L. 1986: A Collection of Medicinal Recipes and Charms. Studies on Alchemy, Diet, Medicine and Prognostication in Middle English, Scripta 22, Brussels, Omirel: 113-143.

Forbes, T. R. 1971: Verbal Charms in British Folk Medicine. Proceedings of the American Philological Society 115: 293-316.

Henslow, G. 1899: Medical Works of the Fourteenth Century: Together with a List of Plants Recorded in Contemporary Writings, with their Identifications. London, Chapman \& Hall.

Holthausen, F. 1897: Rezepte, Segen und Zaubersprüche aus zwei Stockholmer Handschriften. Anglia 19: 77-85.

Hunt, T. 1990: Popular Medicine in Thirteenth-century England: Introduction and Texts. Cambridge, D. S. Brewer.

Jucker, H. A. \& I. Taavitsainen 2013: English Historical Pragmatics. Edinburgh, Edinburgh University Press.

Keiser, G. 1998: A Manual of the Writings in Middle English, 1050-1500. Vol. X. New Haven, The Connecticut Academy of Arts and Sciences.

Mitchel, L. T. 2011: Cultural Uses of Magic in Fifteenth-century England. (Ph.D. dissertation.) Toronto, University of Toronto.

Ogden, M. S. 1938: The "Liber de Diversis Medicines" in the Thornton Manuscript (MS. Lincoln Cathedral A.5.2) (E.E.T.S., o.s. 207). Oxford, Oxford University Press.

Olsan, L. 1992: Latin Charms of Medieval England: Verbal Healing in a Christian Oral Tradition. Oral Tradition 7.1: 116-142.

Olsan, L. 2003: Charms and Prayers in Medieval Medical Theory and Practice. Social History of Medicine 16.3: 343-366.

Olsan, L. 2004: Charms in Medieval Memory. In J. Roper ed. Charms and Charming in Europe. London, Palgrave: 59-88.

Olsan, L. 2005: The Language of Charms in a Middle English Recipe Collection. American Notes \& Queries 18.3: 29-35.

Olsan, L. 2009: The Corpus of Charms in the Middle English Leechcraft Remedy Books. In J. Roper ed. Charms, Charmers and Charming. London, Palgrave: 214237. 
Olsan, L. 2018: Writing on the Hand in Ink: A Late Medieval Innovation in Fever Charms in England. Incantatio 7: 9-45.

Oxford English Dictionary (OED). www.oed.com

Pahta, P. 2004: Code-Switching in Medieval Medical Writing. In I. Taavitsainen \& P. Pahta eds. Medical and Scientific Writing in Late Medieval English. Cambridge, Cambridge University Press: 73-99.

Payne, J. F. 1904: English Medicine in Anglo-Saxon Times. Oxford, Clarendon Press.

Roper, J. ed. 2004: Charms and Charming in Europe. London, Palgrave.

Roper, J. 2009: Introduction: Unity and Diversity in Charm Studies. In J. Roper ed. Charms, Charmers and Charming. London, Palgrave: xiv-xxvii.

Roper, J. ed. 2009: Charms, Charmers and Charming. London, Palgrave.

Smallwood, T. M. 2004: The Transmission of Charms in English, Medieval and Modern. In J. Roper ed. Charms and Charming in Europe. London, Palgrave: 1131.

Smallwood, T. M. 2009: Conformity and Originality in Middle English Charms. In J. Roper ed. Charms, Charmers and Charming. London, Palgrave: 87-99.

Taavitsainen, I., P. Pahta \& M. Mäkinen. 2005: Middle English Medical Texts. CDRom. Amsterdam \& Philadephia, John Benjamins.

Weston, D. 2004: Ferguson, John (1838-1916). In Oxford Dictionary of National Biography, online edition by L. Goldman. Oxford, Oxford University Press. http://www.oxforddnb.com.ezproxy.lib.gla.ac.uk/view/article/53857

Author's address

Departamento de Filología Moderna

University of Alcalá

C/ Trinidad, 3

28801 Alcalá de Henares

Madrid (Spain)

received: 12 November 2020

e-mail: isabel.cruz@uah.es revised version accepted: 10 February 2021 